\title{
Technical and systemic keys and context of Hispanic fortifications on Western Mediterranean coast
}

Fernando Cobos-Guerra

ICOMOS/ICOFORT, Valladolid, Spain, fernandocobosestudio@gmail.com

\begin{abstract}
On recent years, we have developed two new ways of scientific approximation to the study of fortifications: the technical analysis and the systemical analysis. Now, it is possible to recognize a personality and a characteristic technical evolution of the Hispanic fortification departing from the works, the debates, and the treatises generated since the end of 15 th Century to the 18th Century. It is also possible to recognize, since the first periods, a clear intention to understand the fortification as a territorial system in which every single piece has its own mission and presents some specific characters that are not understandable from the independent study of every fortification. The current presentations review the technical and systemical keys that allow us to recognize and characterize the Hispanic fortification on the Western Mediterranean Sea. Those keys allow us to surpass the excessive valuation given to the orthodox following of the treatises and to recognize the value of technological landmark of many of the most heterodoxical fortifications. Those keys also allow us to reinterpret our vision of the landscape value of the fortification from new technical and systemic aspects.
\end{abstract}

Keywords: territorial heritage systems, fortification system, master plan, landscape

\section{Recognition of values in the bastioned fortresses}

Thanks to the interdisciplinary studies and Master Plans, the landscape and legendary values associated at first with fortifications could be enriched with the knowledge of the chronology of construction processes, the typological and stylistic analysis or the documentary contents that the remains provides to the history of general architecture or the history of a specific territory. However, for surpassing the problem that signified the recognition of the artistic and cultural identity values on fortifications (Cobos, $2006 c \& 2013 a)$, on recent years two new values or preferably, two new ways of approaching to the knowledge of fortifications have been developing: the technologic and technical value from the discipline of the art of fortification and the technological innovation that involves on one hand and understanding of the fortification as a piece of a territorial system on the other, and therefore it is able to be studied as a system, increasing the interest on a system which value is more than the simple addition of the values of the buildings that conforms it.

\section{Technological values}

The analysis of the evolution of the defensive systems of the mediaeval castles and, much more intensively, of the Renaissance and the ModernEra fortifications, it introduced a new field of study that, as the building is more recent, it will be more into the fields of History of Science and Technology than Art History. The limited development of the field of the History of Technology in Spain deeply conditioned the 
perception that we had of the fortifications, especially the ones built since the start of the development of the gunpowder technology.

The study of the Renaissance and bastioned fortifications with those new parameters, introduced the concept of landmark or technological value of a fortification, unrelated to other values of historical identification or aesthetic recognition (Cobos 2006; Cobos \& Retuerce 2012, 34).

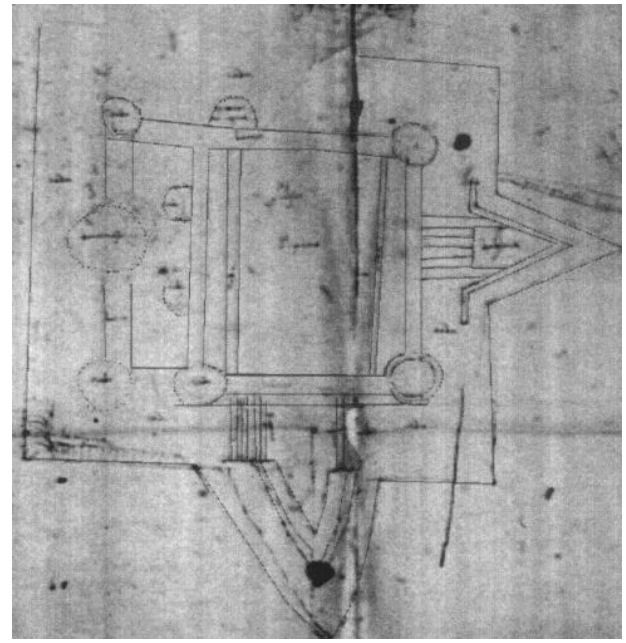

Fig. 1- Plan of Salses Castle during the french siege in 1503 (Cobos \& Castro, 1998b)

This technological alternative necessarily produces a new kind of study and valuation of the fortification from the analysis of the parameters of geometrical and mathematical design of fortifications (Cobos \& Campos, 2013).

Although the first preserved fortification for its technical value it was the Spanish castle of Salses, at Roussillon, due to a report of Vauban in the 17th Century (Cobos, 2005c: 277-78), the recognition of the technological values of the fortification beyond of aesthetic or landscape values it is much more modern and on recent years it has generated a new ways of study and protection keys. This is the case of Ibiza, where those technological values were recognized in the declaration of World Heritage (Cobos, 2006a, 2011c).

\section{Systemic values}

The recognition and characterisation of Territorial Heritage Systems and specifically Territorial Fortification Systems has had an important development in recent years via works developed for local or regional systems. (Retuerce \& Cobos 2004; Zozaya, 2010; Cobos, Castro \& Canal, 2012; Cobos \& Retuerce, 2012: 37-41), for international border systems (Cobos \& Hoyuela, 2010; Cobos, 2011; Cobos \& Campos, 2013) and, in a more global level, via the works developed at ICOMOS International Scientific Committee on Fortifications and Military Heritage (Cobos 2013).

The study and characterisation of Territorial Systems represents the most successful way for being understanding ensembles of fortifications departing from its recognition as parts of a system which allows to interpret them on a more precise way that the individual study of every single one.

In an easy way and following some of previously cited works (Cobos \& Retuerce 2012, 189-19), we can determine the difference among an ensemble of monuments, a tour or an itinerary and a Territorial Heritage System with the following criteria, not always used for the identification of systems: First, the buildings that conforms a system must be coherent from a typological, chronographic, geographic and technological point of view. In other words, the system is a result of a constructive process of buildings built in a specific period, in a specific geographic area and with specific typological or technological characteristics. On a second level, we can differentiate between Proper Systems and Improper Systems.

A Proper System is chronologically, geographically and technologically coherent and also it was conceived as a system when the buildings were erected. In other words, there are system values that are independent from the values of every single monument. The tactical project or the function that every single element performs in the whole system is not understandable with the simple analysis of the particular circumstances of every building. 
An Improper System is the one that being coherent from the chronological, geographical and typological point of view, it was not originally conceived as a system.

From the point of view of heritage value, we can considerate that is an Improper System: Value of the System = Addition of values of elements, while in a Proper System: Value of the System > Addition of values of elements, because there are values that belong to the System as a whole and they are independent of values of every building.

\section{Context and systemic keys}

\subsection{Concept of sea border}

There are some kinds of coastal fortification and not all are settled with the concept of sea border that the Hispanic Monarchy developed from the beginning of 16th. Century (Cobos, 2011).

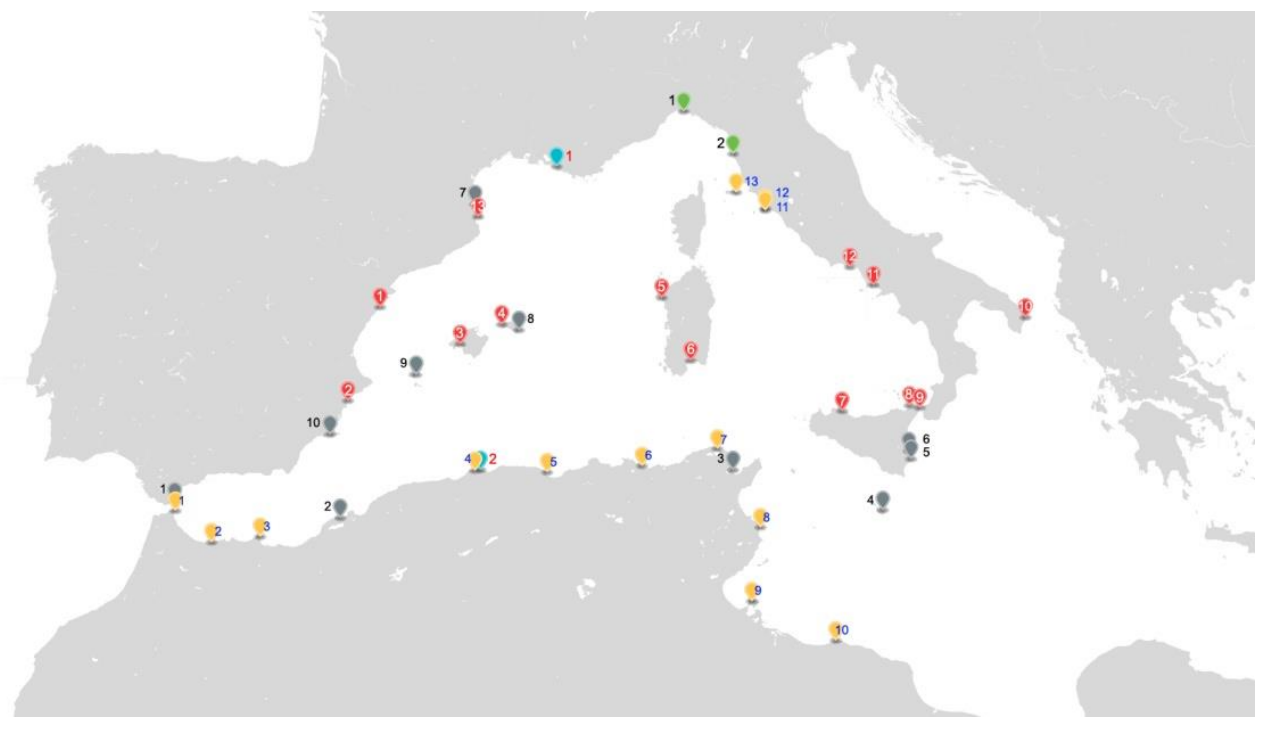

Fig. 2- The Western Mediterranean Sea. Hispanic Sea Borders in the Mediterranean.

Keys (grey). 1. Gibraltar; 2. Oran; 3. Goulette; 4. Valleta; 5. Syracuse; 6. Augusta; 7. Colliure; 8. Mahon; 9. Ibiza; 10 Cartagena. "Presidios" (yellow) 1. Ceuta; 2. Penon de los Velez; 3. Melilla; 4. Algiers; 5. Béjaïa; 6. Bona; 7. Bizerte; 8. Mahdia; 9. Djerba; 10. Tripalo; 11. Porto Ercole; 12. Orbetello; 13. Porto Longone. Own Fortified harbours (red) 1. Peñíscola; 2. Alicante; 3 Palma; 4 Ciudadela; 5 Alghero; 6. Cagliary; 7. Palermo; 8. Milazzo; 9. Messina; 10. Otranto; 11. Naples; 12. Gaeta; 13. Roses. Main Allied Harbours (green) 1. Genoa; 2. Livorno. Main Enemy Harbours (blue) 1. Marseille; 2. Algiers.

There is a coastal fortification with the main mission of contests and prevents the attacks from the sea to the own territory. This coastal fortification has always existed, especially in those coasts where the pirate attacks, which they stealed spoils and prisoners, were more usual. All Mediterranean coasts of the Spanish Crown, in islands and in the Hispanic and Italian peninsulae, present some towers for coast surveillance, completed with small forts for protecting towns or harbours where landings could be performed. The Crown dedicated, since Middle-Ages, great amounts of resources for building a system for prevent those attacks, but this system is not what we exactly consider a sea border. Secondly, there are fortifications that they were used by routes, navigation stops of commercial routes, as the ones developed by Portugal on the African and Asian coasts alternating the stops in ports of proper towns and the commercial interchange stops. This was the first model used by the initial Portuguese and Spanish settlements in America. A special case is the ensemble of fortifications built by the Portuguese on the current coast of Morocco between Ceuta and Cape Rhir and by the Castilians up to Cape Juby. In this case, the 
control of the coast pretended a certain territorial inland dominion, frustrated by reaction of the local kingdoms and definitively forgotten after the disastrous Battle of Ksar-el-Kebir (1578), where King Sebastian I of Portugal was killed.

However, the true concept of sea border corresponds to the strategic approach that the Spanish Crown planned at the beginning of 16th Century for assuring the control of western Mediterranean Sea against the danger of the Turkish armada. The invasion of Otranto by Turks caused concern to Ferdinand "the Catholic", King of Sicilia and pretender to the Naples throne, who he had settled himself as a defender of the Mediterranean Sea, at least as a pretext for sending Aragonese and Castilian troops to the South of Naples, what finished in 1504 with the conquest of the whole Kingdom. The plan of the Spanish King was gaining or disable with own fortifications all the bays or ports big enough for housing an enemy fleet, as he knew that the war galleys on Mediterranean Sea could not survive a tempest without safe harbours, which they were not very numerous. Andrea Doria, the Genovese admiral of the Spanish fleet on the first half of 16th Century, said that he did not know any other safe Mediterranean harbours than "June, July and Cartagena".

With this approach, many forts were built on northern Africa, from Gibraltar to Tripoli, in many cases castles erected on an islet and completely surrounded by enemies, which mission was to prevent the enemy use of the bays. This is the origin of the word "presidio" (lat. praesidium, castle with garrison in the border line), which in nowadays Spanish means an isolated prison where is hard to escape. For example, The rock of Vélez la Gomera, on the African coast, was fortified in 1508 for this reason and still today retains a Spanish fortification cared by some soldiers of the Spanish army, more as a tradition than for tactical reasons. The system obviously included the fortification of the own harbours and it was completed during 16th Century until it constituted a system of absolute control of the western Mediterranean Sea, including allies states as
Genoa and Florence (practically vassals) and with the exception of Algiers, whose rock had been lost and the attempt of conquest it in 1541 it was a failure, and Marseille harbour, whose conquest had failed in 1524. (Cobos, 2012; Cobos, 2013, 45-50).

The organization of the system was based on three categories of fortification.

-The fortification of the main harbours of the fleet, which included arsenals for navy (For example, Cartagena in Spain and Augusta in Sicily) and the so-called "keys", those harbours with high tactical value for the own fleet or for the enemy and whose lost signified the lost of the control of the sea. Among those "keys" there were Gibraltar, Oran, La Goulette, Roses and specially the small islands with big harbours, as the reconquest using the inlands was impossible, as Ibiza, Mahon, or Valetta.

-The fortification of "presidios", that it is, harbours that became fortified, not only for its own use, but for disabling its use by enemy fleets. In the Mediterranean sea, apart from initially fortified on the African coast (Ceuta, Velez, Melilla, Mers-El-Kebir, Oran, Bejaïa, Annaba, Bizerte, Goulette, Mahdia, Djierba, Tripoli), many of them became lost or abandoned on the first half of 16th Century, they are noteworthy the fortifications built for protect the harbours and bays of Monte Argentario and the Island of Elbe on Tuscany coast after the war of Sienna (1557). Among this ensemble, historically know with the meaningful name of "Stato dei presidi", the Spanish forts of Porte Ercole, Orbetello and Porto Azzuro (Porto Longone), they are extraordinary well-preserved.

-The fortification of the secondary and commercial harbours which are not keys or "presidios", but they are fortified for preserve the population and their activity.

Obviously, the inclusion of a harbour or a bay in one of these categories varies time and with the tactical strategies. Some fortified harbours hold always their condition of keys, as Cartagena or Valetta, others get importance grace to significant war occurrences, as Messina, or its occupation by other, as Mahon or Gibraltar. 


\subsection{Local Systems, Sub-systems. Groups and ensembles}

Although the whole system follows a sole and global strategy, inside every system, we can find a local system that applies this strategy in a specific geographic area. The defence of Rousillon against France, it was entrusted to a complex of fortifications that had different functions. Salses, Perpignan at the north of that border line, with its walls and citadel, where the army was located, and Colliure with a high fortified harbour that allowed sending provisions and reinforcements from Spain without crossing the Pyrenees. The subsystem of Spanish fortification at Rousillon, designed in 1497, worked extremely well during the following 150 years.

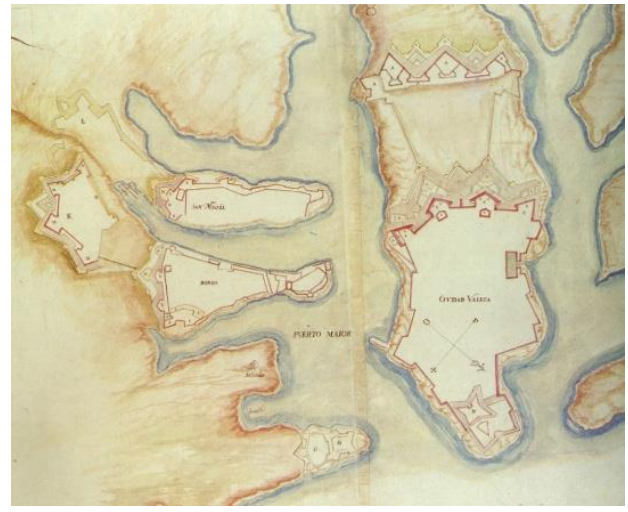

Fig. 3- Description of the Malta fortification with the oppinions of Juan de Médicis and Juan de Garay in F. Negro \& C.M. Ventimiglia, Atlante di citta' e fortrezze del regno di Sicilia, 1640.

Salses, on the first defence line, stopped the enemy and entertained it during months, having the military power and cavalry enough for forcing the enemy to make a siege without passing to Perpignan. Perpignan had powerful walls that defended one of the main cities of the Crown and it had indoors a citadel with a division of the army, cannon foundries and an arsenal. More to the South, there was the fortified harbour which allowed the coming of reinforcements, although Perpignan were at siege. (Cobos, 1998; Cobos, de Castro, 2004, 320-383).

From 1640, on the Border between Castile and Portugal, there were local systems, the complexes of El Miño, around Valença do Miño, the border of Old Castile around Almeida and Ciudad Rodrigo or the border of Guadiana river around Elvas and Badajoz (Cobos 2011), where we can differentiate various kinds of fortifications and strongholds based on their role. On the land borders, unlike the sea ones and with the exception of the case of Sacramento-Buenos Aires in Rio de la Plata, we cannot understand a local system without including the enemy's fortifications as the border line may differ and the fortification system were transverse and perpendicular to the borders.

The difference between a local system and a subsystem is not always clear and the case of Rousillon is in a middle ground. The subsystem groups a complex of fortifications with a correct tactical function, usually a fortification or main stronghold, rearguard and outpost works or enemy's fortifications. The system of CerveraGoyan at El Miño, with a stronghold and four Portuguese forts and three Spanish forts, placed indistinctly on both sides of the river, it could be an example (Cobos, Hoyuela, 2010), or the defensive system of the Spanish "presidio" of Monte Argentario on the Tuscany coast with the defences of Porto Ercole, Orbetello and the other artillery batteries of the peninsula.

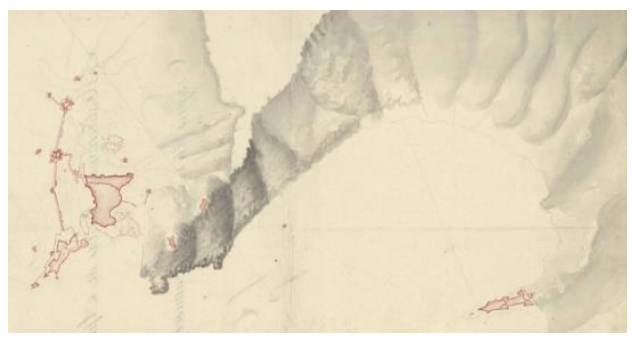

Fig. 4- Sketch of the fortifications of Oran and MarsEl-Kébir, c.1736. Centro Geográfico del Ejército (Spain).

The third sublevel of the system would be made up of ensembles or complexes of fortifications. The lack of soldiers that the Spanish Crown suffered, caused the preference for the development of defensive systems with many small and scattered forts to great fortifications. The defensive system of Oran, on the the Algeline coast, with many coastal castles and on the hills, 
or Porto Ercole, with three fortifications and some batteries, are examples of these groups and ensembles which, on its simplest versions, they usually had, at least, two fort for protect the sides of the bays, alternating side-fortifications with fortifications located on high places that they dominated the whole bay.

\subsection{The logistic and strategic determinants and its extension to the Atlantic}

In the second half of the 16th Century it was clear that any naval victory did not secure the maritime dominion nor any defeat meaner its lost. The success of the Turkish attack to Goulette in 1574 after the crushing Spanish victory at Lepanto in 1571 , or the great disaster, with a great loss of ships and men, of the Drake expedition against Galicia and Portugal in 1589, after the failure of the Spanish army against England, justified what the Turkish vizier said to the venetian ambassador, comparing the destruction of the Turkish fleet with the venetian loss of fortresses and islands:

"You certainly think that we are discouraged by the misadventure that we just have experienced and you come to enjoy at our defeat, but you should know that if you have closely shaven us beating our fleet, we have removed you an arm, taking away your lovely Kingdom of Cyprus and a cut arm cannot revive, but a shaven beard grows up thicker and harder than ever" (Jouanin, Van Gayer, 1840)

Since 1580, when Portugal was incorporated to the Spanish Monarchy, a defensive system of fortifications for protect harbours and "presidios" from Antwerp to Cape Verde -on the eastern coast- and from Florida to the Strait of Magellan -on the western coast- was developed. It is possible, therefore, linking the experience of the defence of the Malta bays from San Telmo fort against the Turks in 1565 with the defence of the mouth of Rio Grande do Norte against the Hollands in 1633, or the defence of La Habana harbour against the English in 1762. It is interesting, therefore, that almost 200 years after the Malta siege, the fort in La Habana had the same strategic mission, as Silvestre Abarca said in his study for the defence of La Habana in 1771:
"If they cannot enter in a harbour, they will be exposed to be destroyed by inclement weather in less than three months."

The Atlantic system was built, basically, between 1580 and 1600 , although some fortifications were completed much later, and we can discriminate, as in the Mediterranean, main harbours for the fleet, arsenals and keys and secondary and commercial harbours. On the eastern coast of the ocean, the main harbour of the English Channel must had been Antwerp, but the Holland threats moved it to Dunkirk and Gravelines, although until the second half of the 17th. Century, with the channel works, there were not secure for great ships. In order to compensate this disadvantage, on the high tension periods with England, the mouths of the bays of Brest and Lorient, on the French coast, were occupied and fortified, and El Ferrol started to emerge as the main harbour for the fleet, initially along with La Coruña. Further South, the two keys of the defensive system were Lisbon, whose coastal defences were multiplied by order of Philipp II, and, of course, Cadiz. The surroundings of Cape San Vicente, Azores, Canary islands and Cape Verde, were also endowed with powerful fortifications in order to defence them.

On the American coast, the first expedition of Aldmiral Valdés with Antonelli as engineer (1581-84), profiled all the defensive system from La Guyana to the Strait of Magellan and the defensive designs and some of the fortifications that defended Salvador do Bahia, Natal, Rio do Janeiro, Santos o Río de la Plata were conceived in this first system. A second and third travel, commanded by Tejada and also with Antonelli as engineer, defined the Caribbean defensive system (1586-88 and 1589-1600). The strategic design of the Atlantic defensive system was the expression of the Mediterranean experience, the choice of the best places for the defence was entrusted to skilled army members (Valdés and Tejada), and, as Rojas proposed on his treatise:

"The third [maxim] and the most important one for fortifications is to know well the place where the fortress must be done [...], which it is a task for old soldiers." (Rojas, 1598) 


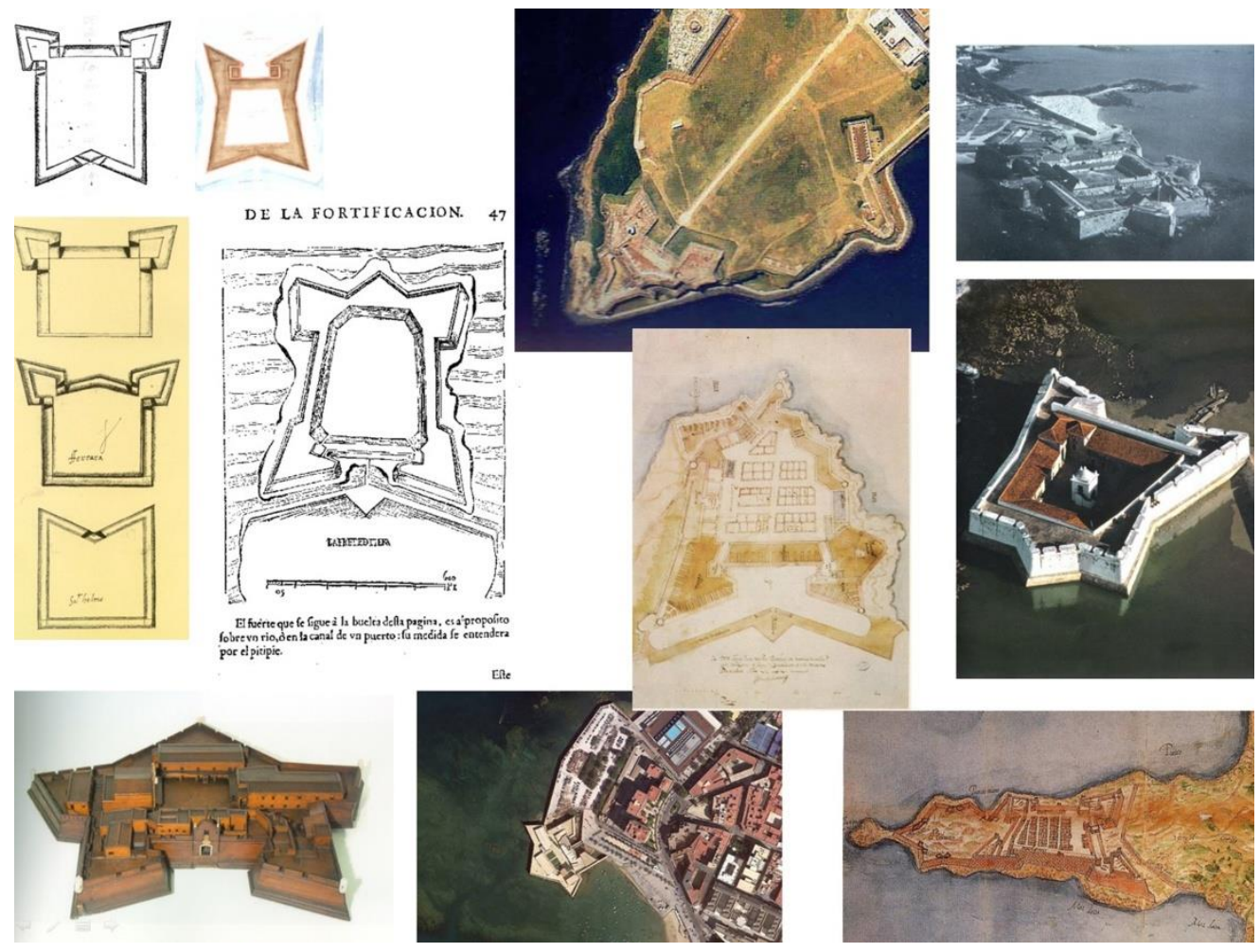

Fig. 5- Comparatives between plain curtains and perced-shaped designs in Escriva's treatise and "morros" design in Spanish fortification. From left to right, in columns: Design of San Telmo at Malta; proposal of Rojas' treatise (1598); model and aerial view of the fort of Santa Catalina at Cádiz, designed by Rojas too. aerial view of the "Morro de San Juan" at Puerto Rico and plan of La Habana "Morro"; Nowadays views of Blavet castle at Port Louis, France and Natal in Brazil, both from the end of 16th Century. Drawing of 1575 of Mars-El-Kébir fort in Oran.

\section{Context and technical keys}

As the choice of the place and the geographic and topographic determinants for the defence were determinant factors in the Hispanic fortifications, we can assure that the built fortifications would be very different depending on the places where it stands. In other words, the main characteristic of the Hispanic fortification is that all the fortresses are different, as it was impossible to reproduce an abstract model. However, it is possible to discriminate a series of invariant characteristics on those fortifications, as some technical solutions as the use of perces instead bastions, they permitted a better adaptation to the environment and economize defence points and garrison (Cobos, Castro, Sanchez-Gijon, 2000; Cobos, 2014). This became especially evident if we compare all the forts built on the hills that they defend the bays, which have a clear precedent in the design that Luis Escrivá made for San Telmo in Naples:

"I do not presume to do laws to force others to follow them if they is not appropriate for themselves... as there is not any place like another one all over, the fortresses must accommodate to their places".

This model of fort in a high place, dominating all the bay, appears in the Spanish "presidios" at Italy, at Oran, Algiers or Setubal and incorporates the design of perces, adapted to irregular places, using all the potentials of the environment. A more regular variant, also star-shaped, started to be used by the Spanish engineers for little forts at heights in Roses (Spain), Colliure (France) or 
Porto Ercole (Italy) on the decades of 1540 and 1550 and later was extended as a model for another "presidios".

On the other hand, the need for protection of the mouths of the bays generated a fort model "de morro", which origin could be the design, under Escrivá's influences, for San Telmo Fort in Valetta, at Malta. If we look all the "morros" built by the Spanish Crown in 16th and 17 th Centuries, we can see that all are different but very alike at last instance, and are based on the principles of fortification defined by Escrivá in 1538, and they also followed the standards that, in a masterful way, Rojas included in his treatise in 1598. (Cobos, 2013a; Cobos, 2013b)

The combination of "de morro" defences and coastal ones, with high-placed forts and town defences or citadels generated a type of harbour and town that began to be recognizable as a new landscape of this fortification system. As the New World or Africa or in many of the Atlantic and Mediterranean "presidios" of Europe, the place was chosen "ex-novo", according to the defence capacities, all the chosen places and the way of placing the city and its fortifications defines an own cultural image recognizable in many cities of the World.

\subsection{The engineers of the Spanish Monarchy}

We have explain in former publications how it was worked the structure of the engineers of the Spanish Crown. Although most of them were direct or indirect subjects or vassals of the Crown, no matter where the were born, the Monarchy moved them to the required places. Also, as the Spanish military engineers were army members commanding troops, they were employed in the places were a permanent army was settled (Italy and Flanders), whereas in Spain, in places without army officers, there were no engineers and when the Crown had to fortify some place not belonging to Italy or Flanders, and engineer from those locations was sent by its governor. It is paradoxical that many of the engineers sent to Spain were Italians, and among the Italians, nor were the most skilled ones, because the best engineers remained in Italy or Flanders except in some very important cases.
From the beginning of 16th Century engineers like commentator San Martin were at Rome or Rhodes, later Alarcon and Pedro Luis Escrivá at Naples or Pedro Prado at Malta, designing the Fort of San Telmo, whereas italians like Tadino di Martinengo or Benedetto de Ravena worked on the Iberian Peninsula. The same could be said about the works or the treatises in Milan or Brussels by Collado, Lechuga, Garay, Chafrión, the First and the Third Marquieses of Leganes, Santans y Tapia or Fernandez de Medrano. Meanwhile Santans was writing his treatise in Brussels, the Portuguese Enriquez de Villergas published his treaty in Madrid. Meanwhile Chafión and Leganés were directing the Spanish School in Milan, which culminated with the publication of their treatise "Escuela de Palas" (1693), Medrano was the principal writer of the Spanish School at Brussels, where dozens of engineers were learning, many of them also Spanish, the German engineers Ferdinand and Carl von Grunennberg fortified the military strongholds of Galicia or Sicily.

Only since the Spanish Succession War, with the arriving of the French Bourbons to the Spanish throne at the beginning of the 18th Century, was settled a true dependence for foreign engineers, mainly French ones, but the repercussions on fortifications built in Spain as in America, were scarce. The scenery of an Empire that now does not dominate Flanders nor Milan had the new schools of fortification to be reorganized. Barcelona at first, followed by Oran, in Algiers coast, following the idea of place the engineers in the places where they were necessary.

\subsection{Schools and periods}

The Holland school can only exist in those places with sinkable lands, it is really difficult to recognize Vauban-style fortifications out of France and the Italian design only really means that the bastions are pentagonal-shaped and, noteworthy, the first treatise upon this way of design (and its critic) is by a Valencian engineer in 1538. It is impossible that a "school" defined by following certain models could serve for design fortifications from Malta to Philippines. Studying the whole complex of fortifications 
along the World and the dozens of treatises and debates generated on the period, we can say that the Iberian fortification (generally known as Hispanic until 17th Century) is eclectic -as it incorporates experiences from all the war sceneries upon the Hispanic dominions-, heterodoxical -as gives more importance to the place shape and the strategic limitations to the reproduction of establish models- and sceptic -as it refuse, by its ecclecticism and heterodoxy, the existence of universally perfect and unassaiable models.

The excellent and numerous studies about the French collection of treatises on the Vauban tradition and about the Mathematics Academy in Barcelona, established with those theories at the beginning of 18th Century, had unbalanced our global vision about the structure and studies of the engineers of the Hispanic Crown of the Empire period. We can say, on a more balanced way, that there were five great periods:

\section{7-1550. The period of experimentation}

The miscalled transitional period, characterized for the great experimental spirit of the proposes, dominated, in the Spanish case, by the army members and engineers. The building of the Salsas Fortress (1497-1503), following the previous projects for la Mota of Medina del Campo or Granada (Cobos, 2007), the fortifications of Fuenterrabia (1527-1530), the fortifications of San Telmo in Naples and de l'Aquila by Escrivá, along with his treaty of 1538 and the pincer-shaped fortifications employed at the Mediterranean by him and Luis Pizaño (Cobos, 2013), are the highlights. In America is noticeable from this period the Fort of $\mathrm{La}$ Concepción, nowadays at Dominican Republic, inspired by La Mota of Medina del Campo.

The first works from this period are characterized by an early option of hiding the main defences in the moat and the development of complex antimine devices (Cobos, 2015). At the end of the period, Escrivá's treatise prefers the pierceshaped defences to the peaks of the bastions oriented to the enemy's troops, reinforces the cautions for protect the side-gunholes, adjust the defence lines to the muskets reaching and postulates the adaptation to the place over the reproduction of regular models (Cobos, 2014b).

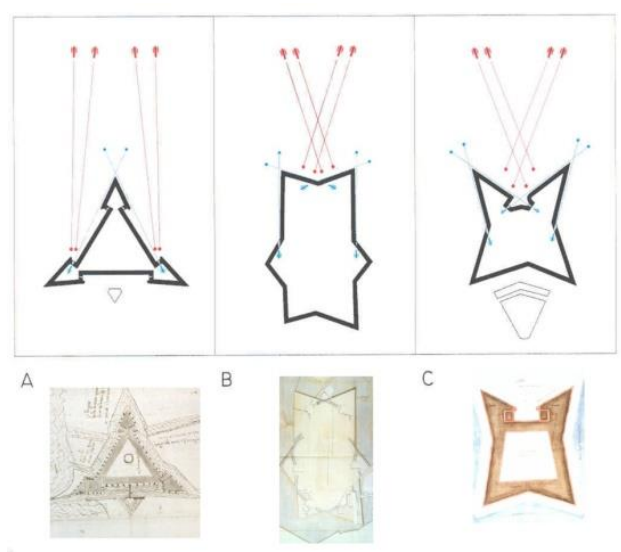

Fig. 6- Fernando Cobos, analysis of the theory of Escrivá about the orientation of the flanked angles oriented to the enemy batteries by Ferramolino at Goulette, compared to Escriva's design of San Telmo in Naples or Pedro Prado's designs for the castle of San Telmo at Malta.

\section{0-1574: the optimism on the Italian design}

It basically corresponds to the period of the great Italian treatises, written and presented for the most part to the Spanish Monarchy, although some were published later. On this period, we can certainly proclaim a theorical dependence on the Italian treatises, when was commonly accepted that the art of fortification was closed, perfect and nearly unassaible, defended by the power of the artillery on the walls. The line of defences is freely adjusted following the reaching of the cannons and the predilection on the types of ideal traces of every tratadist and the regular designs and geometrically perfect, it also corresponds with the period of the utmost military Spanish control. The works of Calvi in Ibiza, the Antwerp citadel or the fortification at Valetta in Malta are its finest examples. In America, we can mention the Castillo de la Fuerza in La Habana. The trust of the Monarchy on these perfect fortification models was broken by the disastrous loss of Goulette in Tunisia against the Turks in 1574.

\section{4-1640: the practical scepticism}

With the Goulette disaster, the Hispanic Monarchy returned to many theories and cautions 
from the experimental period, the defence of the strongholds were again basically entrusted to arquebuses and not to the cannons, the autonomy of the engineers was limited by the presence of fortification expert officers, who were in many cases the true designers of the fortifications, being the engineers confined to draw what the army members issued.

This had happened with Bernardino de Mendoza and Ferramolino in 1538 in Tunisia and it happened again with Vaspasino Gonzaga in Pamplona, in Mers-El-Kebir or in Peñiscola with Fratin, Juan Bautista Antonelli and Bautista Antonelli, respectively engineer-draughtsmen of those fortifications.

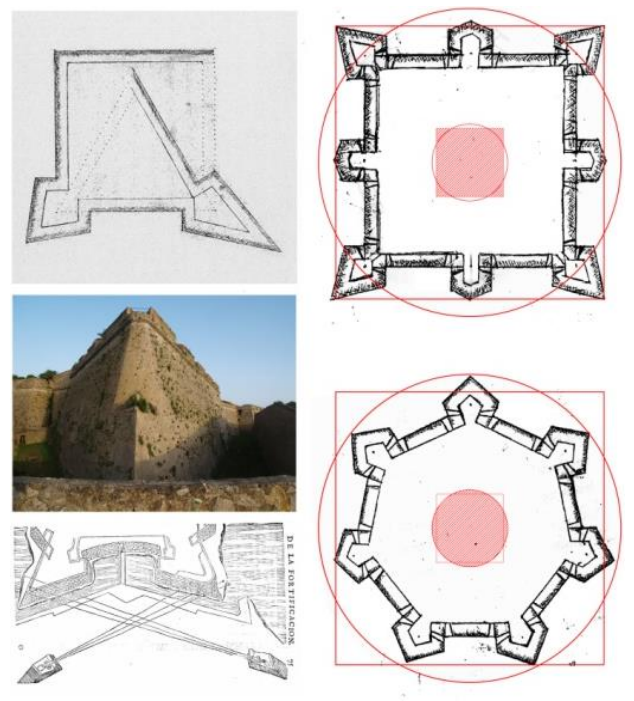

Fig. 7- Left column: Escriva's treatise, 1538, demonstration of how with the less number of sides, a polygon results a more acute bastion and with weaker corners. Forte Filippo, 1557. Spanish "presidios" at Tuscany, notice the rounded flanked angle. Rojas' treatise, 1598: solution with rounded flanked angles in order to avoid its weakness when, by design, it is impossible to make them less acute. On the right: Fernando Cobos Estudio de Arquitectura, analysis of Escrivá's treatise, 1538, design of a quadrangular fortification and a heptagonal one following a square and a circle with the same area, respect that the defiance line distance were less than an arquebus range.

It is possible the most interesting period on American influences, in a mixture of scepticism to the perfect fortification models and pragmatism in the choosing and adaptation to the place that since Escriva's treatise it was a characteristic of the Spanish and HispanicAmerican fortification. The transfer to America of the Mediterranean and the Atlantic Portuguese experiences, of the treatises of Rojas (1598) and Medina-Barba (1599) and later of the Milanese projects of the group of engineers in the service of the First Marquis of Leganes, will settle the basis of a "special way to build" fortifications in America at that moment when the crowns of Portugal and Castile had the same king and the same tactic design (Cobos 2004a).

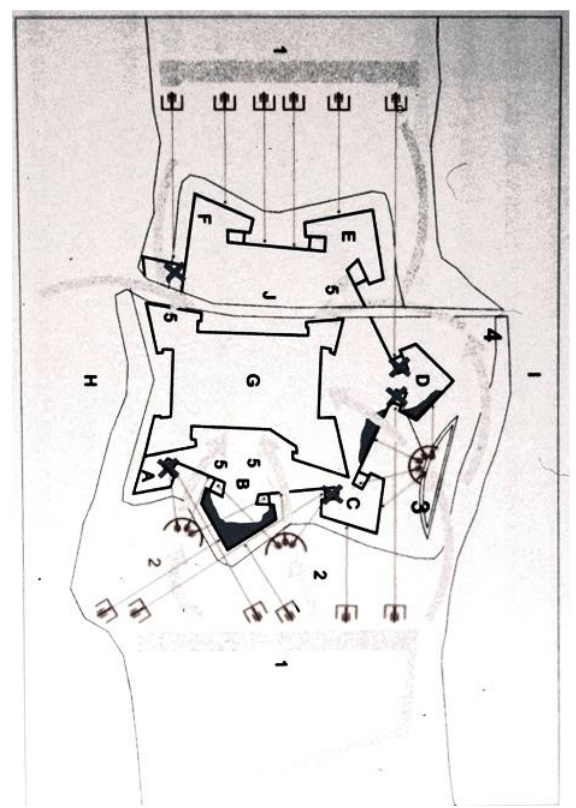

Fig. 8- Sketch of the Turk attack to Goulette in 1574. (Cobos \& Castro, 2000)

The most interesting examples are: in Europe the Habsburg fortifications at Portugal (San Felipe at Setúbal) and Azores and the designs of the Spanish school of Milan for Lombardy and Malta. In America are noteworthy the fortifications of Los Morros de San Juan at Puerto Rico, Santiago and La Habana in Cuba or at Natal and San Salvador de Bahía at Brazil. 


\section{0-1710: the Mathematical empire}

The importance gained by the academies and schools of Mathematics, specially the Jesuitic ones in Spain, Portugal or Flanders, the treatises of the Spanish mathematicians as Caramuel and Zaragoza, the schools of mathematics and fortification of Milan and Brussels, the treatises of fortifications by Santans (1644), Villegas (1651), Mut (1664), and many others, wich culminated in the two great treatises "Escuela de Palas" (Leganés/Chafión, Milan, 1693) and "El arquitecto perfecto en el arte militar" (Fernández de Medrano, Brussels, 1700), they were contemporary with others great treatises, mainly from France and Holland, with the great figures as Vauban and Coenhoorn (Cobos, 2005a). The dominion, if not the tyranny, of the mathematic calculations and the logical preference for the regular fortification (only the regular things are able to be easily calculated) are the main features of this period. Just at the moment, when a model of fortification (miscalled as "Vauban-model"), which it will dominate the first half of the 18th Century, it was defined, the fortification and the Spanish treaties, in constant conflict with France and Holland, adopted eclectic -if not openly sceptic- to the new model and specially to the efficiency of the great regular precincts and the own outer works that Spain had built and intensely experimented in the projects of the first half of the 17th Century. In the European Spanish dominions are noteworthy some projects at Flanders and Lombardy and specially the Messina citadel, designed by Grunenberg. In the last part of the period there are treatises openly critic with mathematical orthodoxy (Cobos, 2013c).

\section{0-1754: the academy of Barcelona and the} Vauban model

Golden period of the regulated education of the engineers, but with the counterpart of the oblivion of many experiences of the Spanish Monarchy, with the submission to the French theories not well adapted to the Spanish defensive requirements nor the resources of the army. Also, they were not capable of evolution in order to adapt themselves to the new war techniques, so they were obsolete about 1750. The Barcelona citadel or the refortification of Portolongue on the coast of Tuscany are the most important examples. In America, the most important example is probably El Callao fort in Peru.

\section{4-1800: disappointment}

Lucuze's revindication for the Spanish treatises and experiences against the French texts, the criticisms of captain-general of engineers Juan Martín Cemeño against the Vaubian models and the projects of the Spanish engineers in America, as Abarca's in Cuba, or Carlos Cabrer's in Montevideo, are the most known examples of the exhaustion of the French theoric models. The most significant examples from the period are the projects of Juan Martín Cermeño for Figueras, Cartagena, Oran and Ciudad-Rodrigo, some of them not executed. In America, are noteworthy the forts designed by Silvestre Abarca in $\mathrm{La}$ Habana.

\section{Study and preservation of the bastioned fortification}

\subsection{Study and preservation of the technical values in fortification}

From romantic landscape to designed landscape of modern fortification. When all castles of Spain were classified in 1949 as monuments $(5,000$ buildings), generically the recognized value for all was their mark on the landscape of the lands of the Iberian Peninsula. When Ibiza's Wall was declared as a national monument in the second half of the $20^{\text {th }}$ Century, for example, the main argument was the view of the wall from the sea. (Cobos, 2008; Cobos, 2011c). We have unconsciously assumed a "picturesque" relationship between the castle and its surrounding territory. This relationship is even more intense when the castle is in ruins and occupies an elevated position. Nevertheless, the castles are not built in those positions for reasons of ostentation of power (although there are many examples, especially in the $15^{\text {th }}$-century and the neo- $19^{\text {th }}$-century castles). The medieval fortifications were at much higher for see more than to be seen. This also affects the use we hope to obtain from a fortress: get on a tower to see the view. However, this is a need that we do not have 
from a church or a monastery. The visual area of a fortification is basically what you see from it. In many cases the location of the fort is conditioned from its origin for this reason. A paradigmatic example of this concept would be the fortifications adapted to artillery from the early $16^{\text {th }}$-century in Europe. Unlike medieval castles and sea fortifications, most of modern fortification, especially if it is well constructed, is not visible from the outside and it has no stamp on the landscape in the romantic sense. This does not mean that it has a perfectly characterized surrounding territory and many times the surrounding has been transformed specifically for the defensive function (Cobos, 2006b).

With successive Carte del Restauro and the methodology developed in recent years, the landscape values initially attributed to the fortification could now be enriched with the knowledge of the chronology of the construction processes and stylistic or typological analysis. It was therefore possible to start assessing fortification based on criteria such as uniqueness, integrity, authenticity, representation, or documentary content that historic remains contributed to the history of architecture or a particular territory. However, in recent years two values are gaining strength, or rather two new ways of approaching knowledge of fortification; from technological and technical from the art of fortification and technological innovation involved on one hand, and on the other, the understanding of fortification as part of a land system and therefore susceptible to be studied as system, increasing the interest on a system whose value is greater than the sum of the values of buildings that compose it (Cobos, Retuerce, 2012).

The bastioned fortification, and especially that of the $17^{\text {th }}$ and $18^{\text {th }}$ Centuries, hidden in the contour of the surrounding countryside, does not have the shine of the medieval walls and their forts do not have the romantic and picturesque component we attribute to medieval castles. But ignoring the most obvious figurative components-covers, buttresses and other architectural elements with defined style décor -, there are some specific characteristics that distinguish it and on which we have previously thought (Cobos, 2004b).

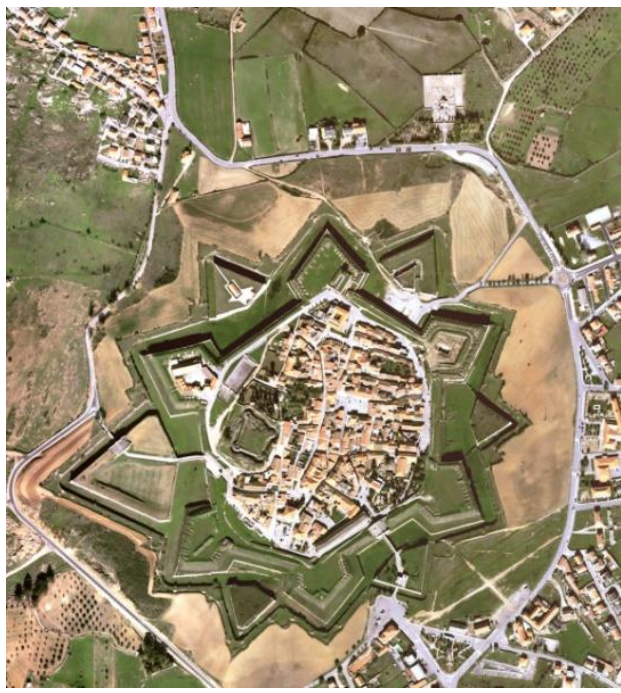

Fig. 9- Aerial view of Almeida (Portugal) (Cobos \& Campos, 2013).

The qualitative leap that establishes the technical assessment of modern fortification, supported by the increasingly developed science and technology history, is crucial to define the conservation criteria outside from the subjectivity of romantic-landscape values and more suitable to the protected object than the simple material preservation of the stones that create the walls. The trace, as a result from a geometric model responds to a precise processing technique; the grade line of the wall, with the balance between dismantle and embankment; design and angles of casemate, embrasures and parapet, and fundamentally, the relationship with the environment, where the outside (ditch, glacis, terrace), it has been modified with geometrical order, free from obstacles, conditioned by the defensive fires, under control of a ruled game of seen and unseen areas. (Cobos, 2004b; Cobos, 2005b). All this defines an artificial landscape totally alien to any other romantic idea of preserving the landscape.

Moreover, the geometric design, that for itself explains what treaty, what trend, what technology are behind each work, is independent from the material that all walls are made. In extreme cases, 
such as earth forts in the Miño riverbank, hidden by the forest, the artificial-natural landscape of the mountain, with ravelins, defensive bastions and hornworks, it is only geometry and nature, without stone or heraldry to distract us (Cobos \& Hoyuela, 2010).

Therefore, it turns out that the most important cultural stamp of scientific knowledge of the bastioned fortification is its layout and not its stones and today, paradoxes of fate, thanks to the spread of satellite image and universal access servers that provide Internet as Google Earth, the trace is the image of the city. Please, try to search Nicosia in Cyprus, and you would verify how, even though the village has eaten the wall, its perfect regular trace is perceived with an infinitely greater force than the impression that any visitor would have being there. Paradoxically, when centuries ago these cities were traced, the layout which defines each design accurately was not perceivable to anyone, and now the trace is no longer a theoretical elaboration only perceived to become the first image of the city. There was a time when the image of the city, as we came from the sea or the field, defined all the city monumental values. Segovia, Lisbon, Toledo, Venice... composed pictures against those invisible bastioned cities could not compete. Now however, when the potential visitor is interested in any bastion city, one of the first pictures he will see is the satellite photo and then from all the city tracks that have shaped its history, there will be nothing as powerful as the starry layout of its walls (Cobos, 2011c).

\subsection{Study and preservation of the system: an own landscape}

Fortification must be understood within a system, but the classification of systems is not an arbitrary modern definition. The truly valuable systems are those that were generated at the time of the fortifications. They represent a way to occupy the territory and a serious influence our perception of the landscape. It is easy to understand: if we consider a set of watchtowers protecting a military route of the Caliphate of Cordoba in the lands of northern Spain, the protection of an environment around each watchtower is meaningless (Cobos, Retuerce, Hervás, 1999). If we understand all the towers as a system the main value of the system is the intervisibility between the towers and the protection of historical landscape acquires a completely different characterization. The same criteria can be applied to a border fortification, a coastline or a complex defensive system (Cobos, De Castro, Canal, 2012). In these cases the relationship between a fortification and other spaces where they could build homes or where they could not, with wooded areas, roads, bridges; they are the elements of a way to establish in the territory, a way of organizing the space (Cobos, 2011a). The development of large land areas in border areas, for example the environment or the city growth was conditioned not only by the built fortifications but also by projects fortifications that were never executed (Cobos \& Campos, 2013).

The fortified coastal cities and the preservation of its seafront

A special case is the fortified landscape of fortified coastal cities. We should consider here the historical, technological and strategic configuration of fortified coastal town aspects. This requires in many cases the reconsideration of typology and key features of each civilization and each technology in shaping this urban image features.

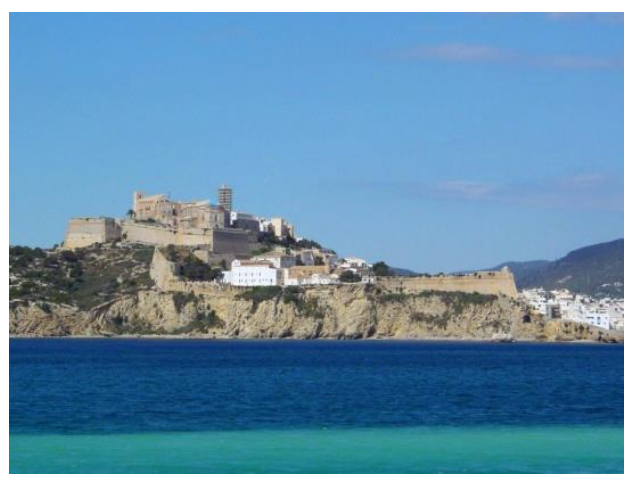

Fig. 10- Sea front of Ibiza (Cobos \& Cámara, 2008)

There are some cities especially in the Mediterranean, where a superposition of implementation strategies is usual, but normally 
and unlike terrestrial cities, the landscape model corresponds to a single project idea. In many cases, because of the clearness of it (the great naval arsenals) and in other cases by the high variability of the marine environment (the image of Cartagena of Spain is basically designed in the $18^{\text {th }}$ Century and has little to do with the Roman or Punic fortified port).

Therefore, it is very important to understand the factors of disturbance and change of the historic cities seafront. On the one hand, we have natural intensive processes such as changes in the coastline (Alexandria, Algiers); military adaptation processes from important historical changes (Cartagena in the $18^{\text {th }}$-century); growth processes of commercial ports which have completely transformed the landscape as in Algeciras or Veracruz; and finally tourism impacts.

\section{References}

Cobos, F. (2000a) "El Plan director de restauración del Castillo de la Mota: metodología de estudio e intervención" in Actas del Congreso Internacional de Restauración del Ladrillo. Sahagún 1999. Valladolid.

Cobos, F. (2000b) "Metodología de Estudio, Diagnóstico e Intervención en Planes Directores de Restauración" in Actas del Congreso internacional de Restaurar La Memoria. Valladolid.

Cobos, F. (2002) "Lectura estratigráfica y restauración de fábricas" in Actas de la I Bienal de Restauració Monumental, L’Hospitalet de Llobregat, Barcelona.

Cobos, F. (2004a) "La formulación de los principios de la Fortificación abaluartada", in Técnica e ingeniería en España: El renacimiento, Manuel Silva, ed., Zaragoza.

Cobos, F. (2004b) "Planes Directores de Restauración, Criterios de Análisis e Intervención en Grandes Conjuntos Fortificados" in Actas del simposium A intervençào no patrimonio práticas de conservaçao e reabilitaçao, Oporto.

Cobos, F. (2004c) "Problems \& Methodology in the study \& repair of fortifications" in Europa Nostra Bulletin, $\mathrm{n}^{\circ} 58$.

Cobos, F. (2004d) "Tecniche ossidionali e difensive aragonesi e spagnole" in Actas del congreso internacional Castel Sismondo e l’arte Militare del Primo Rinascimento, Rimini / "La Artillería de los RR.CC", Valladolid.

Cobos, F. (2004f) "Los orígenes de la Escuela Española de Fortificación del primer Renacimiento" in Artillería y Fortificaciones en la Corona de Castilla durante el reinado de Isabel la Católica, 14741504, Ed. Aurelio Valdés, Ministerio de Defensa, Centro de Publicaciones, Madrid, pp. 225-267.

Cobos, F. (2005a) "La Fortificación Española en los siglos XVII y XVIII: Vauban sin Vauban y contra Vauban”, in Técnica e ingeniería en España: El Siglo de las Luces, Tomo II, Manuel Silva, ed., Zaragoza.

Cobos, F. (2005b) "Los Ingenieros, las Experiencias y los Escenarios de la Arquitectura Militar Española en el S.XVII" \& "Los Sistemas de Fortificación como Patrimonio Heredado" in Cámara, A. (ed.), Los Ingenieros Militares de la Monarquía Hispánica en los Siglos XVII y XVIII, Madrid.

Cobos, F. (2006a) "El Plan Director de las murallas de Ibiza" in Fortificaciones Americanas y la Convención del Patrimonio Mundial, World Heritage Papers, $\mathrm{n}^{\circ}$ 19, pp. 104-112.

Cobos, F. (2006b) "Studies regarding Montearagon castle-convent (Conservation Master Plan for Montearagon castle-convent in Huesca)" in Fortified Churches and Monasteries, Europa Nostra Bulletín, nº6.

Cobos, F. (2006c) "The perception of the value of the bastioned fortifications as monument heritage" in Reconstruction or new construction of medieval castles in the 19th century, Europa Nostra Bulletin, $\mathrm{n}^{\circ} 61$. 
Cobos, F. (2007) “...quien a mi rey no obedeciera de mí se guardara” La arquitectura militar española con Fernando el Católico (1474-1516)", in L'architettura militare nell' età di Leonardo. Edición de Marino Vígano. Locarno.

Cobos, F. (2008) "Engineers and Spanish Fortification schools in Europe and America" in CEAMA, n 1.

Cobos, F. (2009a) "Almeida on the Raia. Report on the fortifications of the Portuguese border line for its designation as a candidate for world heritage site" in CEAMA, $\mathrm{n}^{\circ} 4$.

Cobos, F. (2009b) "Leonardo ingeniero y su contexto: Una guía de lectura crítica del Códice Madrid II" in Los Manuscritos de Leonardo da Vinci de la BNE: Codex Madrid I (Ms. 8937) y Codex Madrid II (Ms. 8936), primera edición crítica y edición facsímil, Madrid.

Cobos, F. (2010a) "Los Castillos de La Mota en Medina del Campo" in Conocer Valladolid, IV Curso de patrimonio cultural, $\mathrm{n}^{\circ}$, pp. 61-87.

Cobos, F. (2010b) "Los procesos constructivos del Castillo de la Mota entre los siglos XII y XV" in Construir la ciudad en la Edad Media. Beatriz Arízaga \& Jesús A. Solórzano, eds. Logroño.

Cobos, F. (2011a) "El sistema de fortificaciones abaluartadas hispano portuguesas como Patrimonio de la Humanidad. Caracterización y valoración del sistema estado de la cuestión” in VVAA, Castillos de España, $\mathrm{n}^{\circ} 164-166$, Madrid

Cobos, F. (2011b) "La huella de la muralla en la ciudad" in VV.AA, Fortificaciones de Pamplona: la vida de ayer y hoy en la ciudad amurallada, Pamplona

Cobos, F. (2011c) "Réhabilitation, gestion et mise en valeur touristique de l'enceinte urbaine d'Ibiza (Espagne)" in In Situ, $\mathrm{n}^{\circ} 16$.

Cobos, F. (2011d) "Enginieers, teatrises and fortification proyects: a transfer of experiencies betwen Europe and America" in Chías, P \& T. Abad (eds.), The Fortified Heritage: a Transaltlantic Relationship, Alcalá de Henares, Universidad de Alcalá.

Cobos, F. (2012) Las escuelas de fortificación hispánicas en los siglos XVI, XVII y XVIII, Patronato del Alcázar de Segovia, Segovia.

Cobos, F. (2013a) "Caracterización y reconocimiento de valores de la fortificación hispánica" in Actas del encuentro anual del Comité Internacional ICOMOS/ ICOFORT, La Habana.

Cobos, F. (2013b) "Las fronteras marítimas de la Monarquía hispánica y los Antonelli: entre el Mediterráneo y América" in Las fortificaciones de los Antonelli en Cuba, siglos XVI-XVII, Galland Books, Barcelona, pp. 45-50.

Cobos, F. (2013c) "Henriques de Villegas, the first great Portuguese treatise writer on Fortification in the 17th century", in CEAMA, $\mathrm{n}^{\circ} 10$, Almeida (Portugal), 2013.

Cobos, F. (2014a) "Recognition and characterisation of the hispanic territorial systems of fortification in the 16th, 17th and 18th Centuries" in CEAMA, $\mathrm{n}^{\circ} 11$.

Cobos, F. (2014b) "Pedro Luis Escrivá y el primer tratado de fortificación moderna. Nápoles 1538" in Camara, A. \& B. Revuelta (coords.), Ingenenieros del Renacimiento, Fundación Juanelo Turriano, Madrid.

Cobos, F. (2015) "The Iberian fortification of rhe first Reinassance (1477-1538) and its influence in the Mediterranian: some technical aspects" in CEAMA, $\mathrm{n}^{\circ} 12$.

Cobos, F. \& A. Cámara (2008) De la fortificación de Yviça. Eivissa: Editorial Mediterrània, Ibiza.

Cobos, F. \& J. Campos (2013) Almeida / Ciudad Rodrigo, la fortificación de la Raya Central, Consorcio Transfronterizo de Ciudades Amuralladas, Salamanca.

Cobos, F. \& J.J. De Castro (1998a) Castilla y León: Castillos y fortalezas, León.

Cobos, F. \& J.J. De Castro (1998b) "Salsas y la fortificación de transición española" in Castillos de España, $\mathrm{n}^{\circ}$ 110-111, Madrid.

Cobos, F. \& J.J. De Castro (2000) "El debate en la fortificación del Imperio de Carlos V" in Las fortificaciones de Carlos $V$. Madrid.

Cobos, F. \& J.J. De Castro (2002) Castillo de Ponferrada, Edilsa, León. 
Cobos, F., De Castro, J.J. \& R. Canal (2012) Castros y recintos en la frontera de León en los siglos XII y XIII. Fortificaciones de tapial de cal y canto o mampostería encofrada, Consejería de Cultura y Turismo, Junta de Castilla y León, Valladolid.

Cobos, F.. De Castro, J.J., \& A. Sánchez-Gijón (2000) Luis Escrivá, su Apología y la Fortificación Imperial, Biblioteca Valenciana, Valencia.

Cobos, F. \& A. Hoyuela (2005) "Metodología de Estudio e intervención del Plan Director de las Fortalezas Fronterizas del Bajo Miño" in Actas del tercer congreso de castillología ibérica, Guadalajara.

Cobos, F. \& A. Hoyuela (2010) "Plano Director das fortalezas Transfronteriças do Baixo Minho" in CEAMA, $\mathrm{n}^{\circ} 5$, Almeida (Portugal).

Cobos, F. \& M. Retuerce (2010) El castillo de Cornatel en Priaranza del Bierzo (León), Fundación del Patrimonio Histórico de Castilla y León, Madrid.

Cobos, F. \& M. Retuerce (2012) Metodología, valoración y criterios de intervención en la arquitectura fortificada de Castilla y León, Consejería de Cultura y Turismo, Junta de Castilla y León, Valladolid.

Cobos, F., Retuerce, M. \& M.A. Hervás (1999 “Apuntes sobre el control del territorio del Duero Superior en la edad Media. Diagrama estratigráfico territorial" in Actas del V Congreso de Arqueología Medieval Española, Valladolid.

Cooper, E. (1980), Castillos señoriales de Castilla s.XV y XVI, Fundación Universitaria Española, 2 vols, Madrid.

De Rojas, C. (1598) Teórica y Práctica de fortificación con forme a las medidas y defensas destos tiempos, Facsimile, ed. Mariátegui, El capitán Cristóbal de Rojas, Ingeniero Militar del siglo XVI, Madrid.

González De Medina Barba, D. (1599), Examen de fortificación, Madrid.

Santans y Tapia, J. (1644) Tratado de fortificacion militar destos tiempos breve e intelegible puesto en uso en estos estados de Flandes, Bruselas.

Villegas, D. (1651) Academia de fortificacion de plazas y nuevo modo de fortificar una plaza real diferente en todo de todos que se hallan en los autores que desta ciencia y arte escrivieron, Madrid.

http://www.fernandocobosestudio.com 